\title{
PENGARUH KESADARAN MEREK DAN PERSEPSI KUALITAS TERHADAP KEPUTUSAN MEMBELI SECARA ONLINE MELALUI KEPERCAYAAN MEREK PADA E-COMMERCE SHOPEE DI KOTA BANJARMASIN
}

\author{
Rusmanida \\ Mahasiswa Magister Manajemen Pascasarjana Universitas Islam Malang \\ Email : rusmanida1994@gmail.com
}

\begin{abstract}
Abstrak
Tujuan penelitian ini adalah untuk mengetahui pengaruh kesadaran merek dan persepsi kualitas terhadap keputusan membeli secara online melalui kepercayaan merek pada e-commerce shopee di Kota Banjarmasin. Jenis penelitian yang digunakan dalam penelitian ini yaitu Penelitian Korelasional (hubungan) untuk menemukan apakah terdapat hubungan antara dua variabel atau lebih, serta seberapa besar korelasi dan yang ada diantara variabel yang diteliti dengan pengambilan sampel sebanyak 57 responden.

Hasil penelitian ini menunjukkan bahwa pengaruh total antara variabel kesadaran merek terhadap keputusan membeli positif dapat diartikan bahwa semakin tinggi kepercayaan merek maka keputusan membeli akan semakin meningkat. Begitu juga dengan pengaruh total antara variabel persepsi kualitas terhadap keputusan membeli positif dapat diartikan bahwa semakin tinggi persepsi kualitas maka keputusan membeli akan semakin meningkat.
\end{abstract}

Kata Kunci: Kesadaran Merek, Persepsi Kualitas, Kepercayaan Merek, Keputusan Membeli

\begin{abstract}
The purpose of this study was to determine the effect of brand awareness and percevied on online buying decisions through brand trust in e-commerce shopee in Banjarmasin City. The type of research used in this study is Correlational Research (relationship) to find out whether there is a relationship between two or more variables, and how much correlation and existing variables are examined with a sample of 57 respondents.

The results of this study indicate that the total influence between the brand awareness variable on the buying decision a positive can be interpreted that the higher brand trust then the buying decision will increase. Likewise, the total influence between the variables of quality perception of positive buying decisions can be interpreted that the higher the percevied quality then the decision to buy will increase.
\end{abstract}

Keywords: Brand Awareness, Perceived Quality, Brand Trust, Buying Decision

\section{PENDAHULUAN}

Perkembangan teknologi informasi yang sedimikian cepatnya telah membawa dunia memasuki era baru yang lebih cepat dari yang pernah dibayangkan sebelumnnya. Setidak-tidaknya ada empat era penting sejak ditemukannya komputer sebagai alat pengolah data sampai dengan era internet dimana komputer menjadi senjata utama dalam berkompetisi. Penggabungan antara teknologi komputer dengan 
telekomunikasi telah menghasilkan suatu revolusi di bidang sistem informasi. (Januar, 2015)

Menurut internet world Stats di peringkat pengguna internet dunia, indonesia menempati peringkat ke lima. Indonesia hanya kalah dengan china, india, amerika dan brazil. Perkembangan teknologi informasi yang sedimikian cepatnya telah membawa dunia memasuki era baru yang lebih cepat dari yang pernah dibayangkan sebelumnnya. Setidaktidaknya ada empat era penting sejak ditemukannya komputer sebagai alat pengolah data sampai dengan era internet dimana komputer menjadi senjata utama dalam berkompetisi. Penggabungan antara teknologi komputer dengan telekomunikasi telah menghasilkan suatu revolusi di bidang sistem informasi. (Januar, 2015)

Menurut internet world Stats di peringkat pengguna internet dunia, indonesia menempati peringkat ke lima. Indonesia hanya kalah dengan china, india, amerika dan brazil.

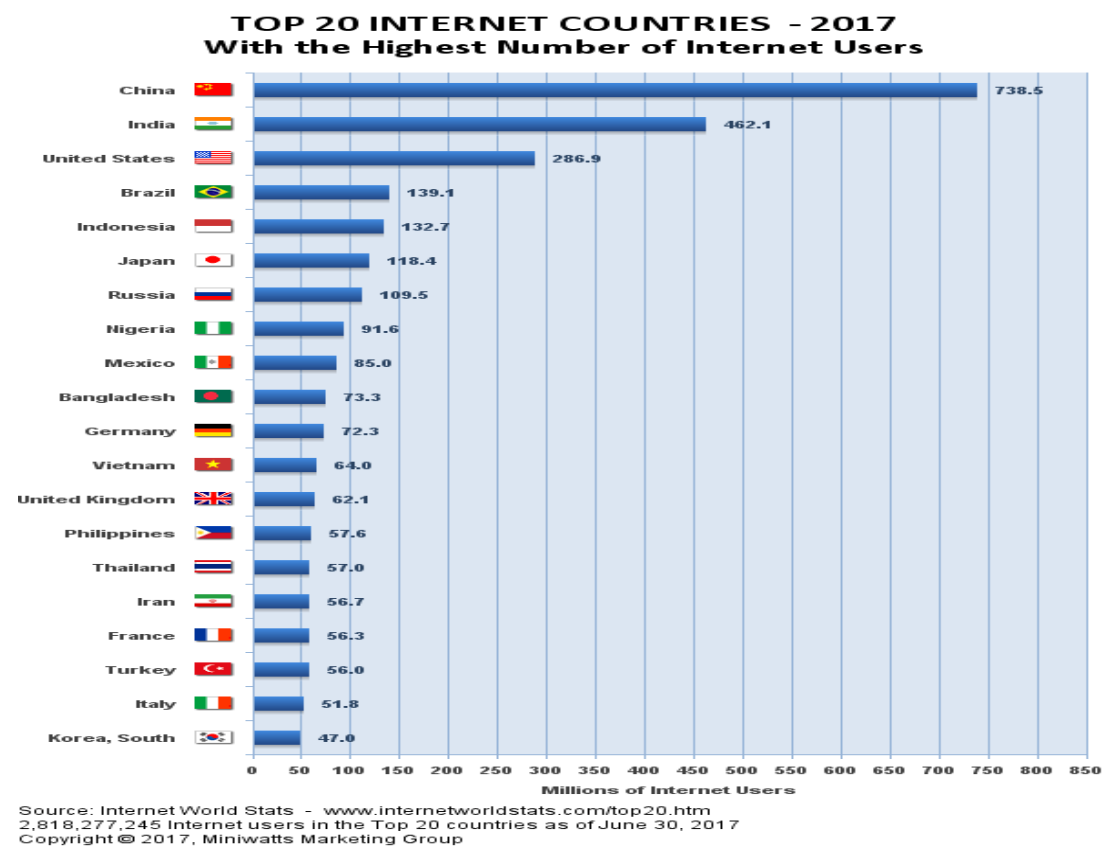

Terdapat 5 model bisnis e-commerce di Indonesia, yaitu Iklan Baris, Marketplace C2C, Shopping mall, Toko online B2C, Toko online social media. Salah satu model bisnis e-commerce yang banyak digunakan adalah Marketplace C2C. Hal ini dikarenakan pada model Marketplace C2C kegiatan jual beli harus menggunakan fasilitas transaksi online seperti layanan escrow atau rekening pihak ketiga untuk menjamin keamanan transaksi. Penjual hanya akan menerima uang pembayaran setelah barang diterima oleh pembeli. Selama barang belum sampai, uang akan disimpan di rekening pihak ketiga. Apabila transaksi gagal, maka uang akan 
dikembalikan ke tangan pembeli. Fasilitas ini memberikan kenyamana $\mathrm{n}$ bertransaksi bagi penjual maupun pembeli. (Lukman, 2014)

Salah satu aplikasi Marketplace yang sedang marak digunakan adalah Shopee. CEO Shopee, Chris Feng mengatakan Shopee adalah satu dari banyak pihak yang memanfaatkan peluang bisnis E-Commerce dengan meramaikan segmen mobile Marketplace melalui aplikasi mobile mereka untuk mempermudah transaksi jual beli melalui perangkat ponsel. Secara general, Shopee sendiri memposisikan dirinya sebagai aplikasi Marketplace. Pendekatan sosial tersebut dipilih karena Asia Tenggara merupakan kawasan yang gemar bermain media sosial. Bukan rahasia lagi bila Indonesia adalah negara yang paling aktif bermain di ranah media sosial. (Priambada, 2015) Bahkan di Indonesia penggunaan media sosial bukan hanya untuk berkomunikasi tetapi juga sudah merambah ke kegiatan jual beli.

\section{KAJIAN TEORI}

Humdiana (2005) mendefinisikan kesadaran merek sebagai kesanggupan seorang calon pembeli untuk mengenali atau mengingat kembali bahwa suatu merek merupakan bagian dari kategori produk tertentu. Kesadaran (awareness) menggambarkan keberadaan merek di dalam pikiran konsumen, yang dapat menjadi penentu dalam beberapa kategori dan biasanya mempunyai peranan kunci dalam ekuitas merek Humdiana (2005).

Persepsi kualitas merupakan persepsi pelanggan atas atribut yang dianggap penting baginya (Astuti dan Cahyadi, 2007). Menurut Zeithaml dalam Muafi dan Effendi (2001) persepsi kualitas diartikan sebagai persepsi pelanggan terhadap keseluruhan kualitas atau keunggulan suatu produk atau jasa layanan berkenaan dengan maksud yang diharapkan.

Kepercayaan merek adalah kemampuan merek untuk dipercaya (brand reliability), yang bersumber pada keyakinan konsumen bahwa produk tersebut mampu memenuhi nilai yang dijanjikan dan intensi baik merek (brand intention) yang didasarkan pada keyakinan konsumen bahwa merek tersebut mampu mengutamakan kepentingan konsumen menurut Delgado dalam jurnal Ferrinnadewi (2008).

Pengertian keputusan pembelian menurut Helga Drumond (2003:68), adalah mengidentifikasikan semua pilihan yang mungkin untuk memecahkan persoalan itu dan menilai pilihan-pilihan secara sistematis dan obyektif serta sasaran-sasarannya yang menentukan keuntungan serta kerugiannya masing-masing. Sedangkan definisi keputusan pembelian menurut Nugroho (2003:38) adalah proses pengintegrasian yang mengkombinasi sikap pengetahuan untuk mengevaluasi dua atau lebih perilaku alternatif, dan memilih salah satu diantaranya.

Dalam penelitian ini dapat dibuat suatu kerangka pemikiran yang dapat menjadi landasan dalam penulisan ini, yang pada akhirnya akan dapat diketahui variabel mana yang paling berpengaruh dominan dalam keputusan pembelian konsumen. Kerangka pemikiran ini dapat digambarkan sebagai berikut : 


\section{Gambar 2.1}

\section{Kerangka Konseptual}

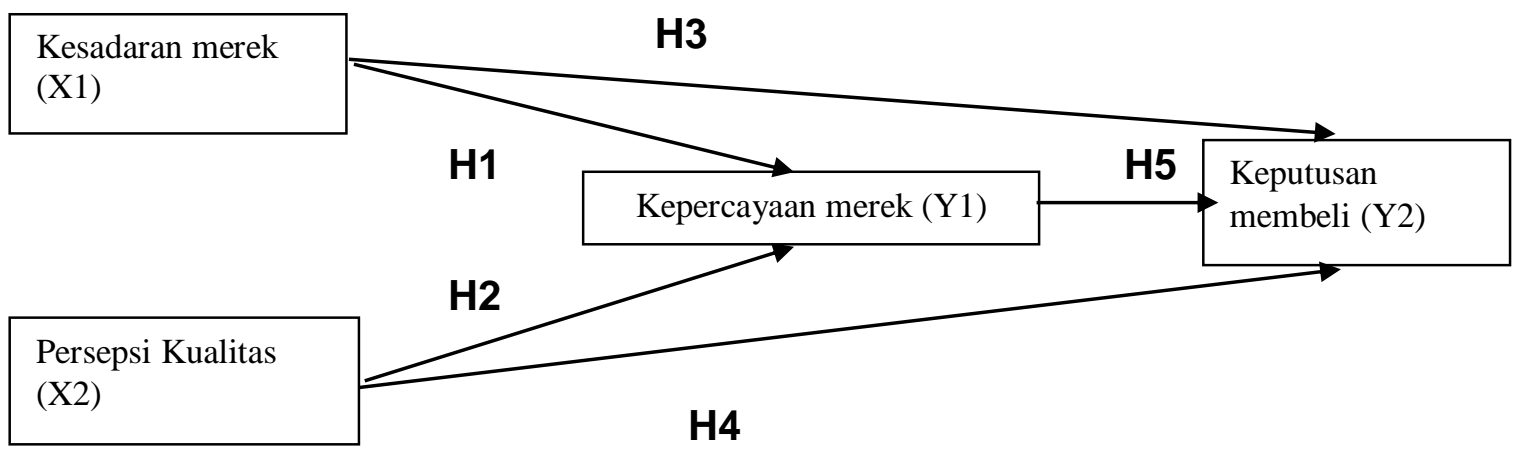

Hipotesis - hipotesis dalam penelitian ini adalah sebagai berikut :

$\mathrm{H} 1$ : Kesadaran merek berpengaruh terhadap kepercayaan merek pada E-Commerce Shopee

H2: Persepsi merek berpengaruh terhadap kepercayaan merek pada E-Commerce Shopee

H3: Kesadaran merek berpengaruh terhadap keputusan membeli pada E-Commerce Shopee

$\mathrm{H} 4$ : Persepsi merek berpengaruh terhadap keputusan membeli pada $E$ Commerce Shopee

H5: Kepercayaan merek berpengaruh terhadap keputusan membeli $E$ Commerce Shopee

H6: Kesadaran merek dan persepsi merek berpengaruh tidak langsung terhadap keputusan membeli melalui kepercayaan merek pada $E$ Commerce Shopee

\section{METODE PENELITIAN}

Penelitian adalah salah satu media yang dipakai dalam menulis dengan prosedur yang telah ditentukan (masyhuri dan Zainuddin, 2008:8). Jenis penelitian yang digunakan dalam penelitian ini yaitu Penelitian Korelasional (hubungan) untuk menemukan apakah terdapat hubungan antara dua variabel atau lebih, serta seberapa besar korela dan yang ada diantara variabel yang diteliti.

Populasi dalam penelitian ini adalah jumlah keseluruhan karyawan Dinas Pariwisata dan Kebudayaan Kota Banjarmasin. Adapun jumlah karyawan seluruhnya adalah 57 orang. Pengambilan sampel dilakukan secara non acak berupa quota sampling, yaitu sampel diambil pada anggota populasi (karyawan) yang berada di karyawan Dinas Pariwisata dan Kebudayaan Kota Banjarmasin. 
Berdasarkan kerangka konseptual penelitian pada Gambar 2.1, terdapat 2 (dua) buah substruktur. Substruktur pertama adalah hubungan kausal dari X1 (Kesadaran Merek) dan X2 (Persepsi Kualitas) ke Y1 (Kepercayaan Merek ); substruktur kedua adalah hubungan kausal dari X1 (Kesadaran Merek), X2 (Persepsi Kualitas), dan Y1 (Kepercayaan Merek) ke Y2 (Keputusan Membeli). Pada substruktur pertama, X1 (Kesadaran Merek) dan X2 (Persepsi Kualitas) merupakan variabel eksogen (variabel penyebab) dengan Z (Kepercayaan Merek) sebagai variabel endogennya (variabel akibat). Sedangkan pada substruktur kedua, X1 (Kesadaran Merek), X2 (Persepsi Kualitas), dan Y1 (Kepercayaan Merek) merupakan variabel eksogen dan Y2 (Keputusan Membeli) sebagai variabel endogen. Analisis data penelitian menggunakan analisis jalur ( path analiysis )

\section{HASIL ANALISIS DATA}

Hasil koefisien jalur pengaruh pengaruh kesadaran merek dan persepsi kualitas dan kepercayaan merek terhadap keputusan membeli di e-comerce shopee. R Square menunjukan nilai sebesar menunjukan nilai 0,528 atau $52,8 \%$. Hasil ini menunjukan bahwa kesadaran merek dan persepsi kualitas dan kepercayaan merek memberikan kontribusi terhadap keputusan membeli).

Hasil uji validitas menunjukkan masing-masing butir pertanyaan mempunyai nilai $r$ hitung $>r$ tabel berarti skor butir berkorelasi secara signifikan dengan total skor, dengan kata lain item yang digunakan mampu mengukur variabel yang diteliti sehingga seluruh item pertanyaan dinyatakan valid.

Hasil uji reliabilitas dapat diketahui bahwa nilai reliabilitas yang dicapai pada masing-masing variabel lebih besar dari 0,6 artinya instrumen yang digunakan reliabel.

Hasil koefisien jalur pengaruh kesadaran merek dan persepsi kualitas terhadap kepercayaan merek. $\mathrm{R}$ square menunjukan nilai sebesar menunjukan nilai 0,471 atau $47,1 \%$. Hasil ini menunjukan bahwa kesadaran merek dan persepsi kualitas memberikan kontribusi terhadap kepercayaan merek.

Hasil koefisien jalur pengaruh pengaruh kesadaran merek dan persepsi kualitas dan kepercayaan merek terhadap keputusan membeli di e-comerce shopee. R Square menunjukan nilai sebesar menunjukan nilai 0,528 atau $52,8 \%$. Hasil ini menunjukan bahwa kesadaran merek dan persepsi kualitas dan kepercayaan merek memberikan kontribusi terhadap keputusan membeli.

Pengaruh tidak langsung antara kesadaran merek terhadap keputusan membeli melalui variabel kepercayaan merek dikarenakan Pengaruh langsung antara kesadaran merek terhadap keputusan membeli signifikan dan pengaruh langsung antara kesadaran merek terhadap keputusan membeli juga signifikan.

Pengaruh tidak langsung antara Persepsi kualitas terhadap Keputusan membeli melalui variabel Keputusan membeli dikarenakan Pengaruh langsung antara Persepsi kualitas terhadap Keputusan membeli 
signifikan dan pengaruh langsung antara Persepsi kualitas terhadap Keputusan membeli juga signifikan.

$\mathrm{H}_{1}$ : ada pengaruh signifikan antara kesadaran merek terhadap Kepercayaan merek

$\mathrm{H}_{2}$ : ada pengaruh signifikan antara persepsi kualitas terhadap kepercayaan merek.

$\mathrm{H}_{3}$ : ada pengaruh signifikan antara kepuasan kerja terhadap keputusan membeli.

$\mathrm{H}_{4}$ : ada pengaruh signifikan antara Persepsi kualitas terhadap keputusan membeli.

$\mathrm{H}_{5}$ : ada pengaruh signifikan antara kepercayaan merek terhadap keputusan membeli .

$\mathrm{H}_{6}$ : ada pengaruh signifikan tidak langsung antara kesadaran merek dan persepsi kualitas terhadap keputusan membeli melalui kepercayaan merek

\section{PEMBAHASAN}

Pengaruh total variabel kesadaran merek terhadap keputusan membeli diperoleh dari penjumlahan pengaruh langsung antara variabel kesadaran merek terhadap keputusan membeli dengan pengaruh tidak langsung antara variabel kesadaran merek terhadap keputusan membeli melalui variabel kepercayaan merek sehingga pengaruh totalnya sebesar $0,247+0,326=0,573$. pengaruh total antara variabel kesadaran merek terhadap keputusan membeli positif dapat diartikan bahwa semakin tinggi kepercayaan merek maka keputusan membeli akan semakin meningkat.

Pengaruh total variabel persepsi kualitas terhadap keputusan membeli diperoleh dari penjumlahan pengaruh langsung antara variabel persepsi kualitas terhadap keputusan membeli dengan pengaruh tidak langsung antara variabel persepsi kualitas terhadap keputusan membeli melalui variabel kepercayaan merek sehingga pengaruh totalnya sebesar $0,208+0,414=0,622$, pengaruh total antara variabel persepsi kualitas terhadap keputusan membeli positif dapat diartikan bahwa semakin tinggi persepsi kualitas maka keputusan membeli akan semakin meningkat.

\section{SIMPULAN DAN SARAN}

Berdasarkan hasil pembahasan yang telah diuraikan pada bab sebelumnya, Maka dapat diambil simpulan sebagai berikut:

1. Ada pengaruh antara kesadaran merek terhadap kepercayaan merek pada E-commerce Shopee di Kota Banjarmasin. Hal ini bermakna bahwa jika kesadaran merek karyawan di tingkatkan maka akan meningkatkan pula kepercayaan merek.

2. Ada pengaruh persepsi kualitas terhadap kepercayaan merek pada Ecommerce Shopee di Kota Banjarmasin. Dengan kata lain jika persepsi kualitas meningkat menjadi lebih baik, Maka kepercayaan merek juga akan meningkat.

3. Ada pengaruh kesadaran merek terhadap keputusan membeli pada Ecommerce Shopee di Kota Banjarmasin. Dengan demikian, jika kesadaran merek di tingkatkan, Maka akan meningkatkan keputusan membeli pada E-commerce Shopee. 
4. Ada pengaruh persepsi kualitas terhadap keputusan membeli pada Ecommerce Shopee di Kota Banjarmasin. Dengan kata lain jika persepsi kualitas ditingkatkan maka keputusan membeli akan menjadi lebih baik.

5. Ada pengaruh komitmen terhadap keputusan membeli pada Ecommerce Shopee di Kota Banjarmasin. Hal ini juga dapat dimaknai bahwa jika kepercayaan merek ditingkatkan, maka keputusan membeli akan meningkat.

6. Ada Pengaruh tidak langsung antara persepsi kualitas terhadap keputusan membeli melalui kepercayaan merek pada E-commerce Shopee di Kota Banjarmasin.

\section{DAFTAR PUSTAKA}

A Aaker, David A. (2008) Manajemen Ekuitas merek. Jakarta: Mitra Utama Amstrong, M. (2002). Performance Management. Kogan Page Ltd. New York. A. Shimp

Humdiana. 2005. "Analisis Elemen-Elemen Ekuitas Merek Produk Rokok Merek Djarum Black." Jurnal Ekonomi Perusahaan, Vol.12, No.1 Maret 2005

Indriantoro, Nur dan Bambang Supomo. 2002. Metodologi Penelitian Bisnis. Edisi 1. Penerbit BPFE. Yogyakarta.

Kotler, Philip. (2000). Manajemen Pemasaran. Jilid 2. Jakarta. Bumi Aksara.

Kotler, Philip dan K. L. Keller. (2007). Manajemen Pemasaran, Ed.12. jilid1. Jakarta: Indeks

Kotler, Philip. (2009). Manajemen Pemasaran (Terjemahan) Jilid 9. Jakarta : PT. Prehallindo.

Mashyuri M, (2015) Optimization of Cassava Distribution and Marginal Area Usage for Supporting Food Endurancelnternational Journal of Applied Engineering Research (IJAER) Vol.10 No.19

Masyhuri dan M. Zainuddin, Metodologi Penelitian (Pendekatan Praktis dan

aplikatif), (bandung: PT Refika Aditama, 2008), cet. Ke-1, hal. 8.

Sugiyono. 2008. Metode Penelitian Bisnis. Bandung: Alfabeta

Sugiyono, (2010). Metode Penelitian Kuantitatif Kualitatif dan R\&D.

Bandung: Alfabeta

Susanto, A. B. (2007). Manajemen Pemasaran. Jakarta : PT. Prenhalindo.

Swastha, Basu dan Irawan. (2000). Manajemen Pemasaran Modern. Liberty. Jakarta.

Tjiptono, Fandy. (2002). Strategi Pemasaran. Yogyakarta : Penerbit Andi. 